Europäische Kommission (20II): Pressemitteilung IP/II/ıOI9, URL: http://goo.gl/2nqPz. Krugman, P., Wells, R. (20I0): Volkswirtschaftslehre, Stuttgart.

Oberhauser, A. (1985): Das Schuldenparadox, Jahrbücher für Nationalökonomie und Statistik, Bd. $200 / 4,333-348$.

Projektgruppe Gemeinschaftsdiagnose (2009): Im Sog der Weltrezession. Gemeinschaftsdiagnose Frühjahr 2009, ifo Schnelldienst 8, 3-8I.

Sachverständigenrat zur Begutachtung der gesamtwirtschaftlichen Entwicklung (2002): Zwanzig Punkte für Beschäftigung und Wachstum. Jahresgutachten 2002/03, Stuttgart.

Scherf, W. (1989): Zur Abgrenzung verschiedener Arten der Staatsverschuldung, Jahrbücher für Nationalökonomie und Statistik, Bd. 206/2, I36-I5I.

Scherf, W. (20II): Öffentliche Finanzen, 2. Auflage, Konstanz, München.

\title{
Rejuvenating the Renewal of Political Economy: The International Initiative for Promoting Political Economy (IIPPE)
}

\section{Dimitris Milonakis*}

\section{Setting the scene}

Following the global economic meltdown of September 2008 and the ensuing economic depression, we are now experiencing what is arguably the third phase of the crisis, that of the eurozone and national debt, with a variety of countries within the eurozone facing the threat of default. In the global North, economic policies have neither ended the neoliberal agenda nor curbed the demands of a resurgent financial sector. Instead, after a pseudo-Keynesian moment centred on 'quantitative easing the governments of the richest countries have launched a new set of neoliberal assaults characterised by the harshest of austerity measures. From 2009 onwards, this resurgent neoliberal wave has spread progressively from peripheral European countries to the UK, the eurozone, and now the USA. Along with rocketing unemployment, particularly among the young, this economic onslaught, on those who are in no way perceived as accountable for the crisis and slump, promises a period of major social disruption in welfare provision and institutions, pressures on wages and working conditions

* Department of Economics, University of Crete.

(C) INTERVENTION 9 (2), 20I2, I88-I93 
and, in response across a growing number of countries, multitudes of spontaneous and, occasionally, mass actions as macroeconomic prospects deteriorate.

In the global South, the forces putatively driving development, catch-up, or convergence, to employ the vernacular, remain limited and highly uneven, with the issue of global imbalances often placed at the forefront in deference to the US's compromised if continuing hegemonic role. In contrast, not least in the face of the ongoing ecological disruption, the idea of a new frontier for social and economic development and thought is being promoted by a large spectrum of actors, ranging from proponents of no-growth or slow growth through to governments, international institutions and corporations who envisage a revival of capitalism thanks to, and in pursuit of, the green economy. These initiatives are indicative of an intellectual and material crisis but offer little by way of solution for which, as observed, a savage renewal of neoliberalism serves as the default option. The scientific issues raised by the corresponding range of problems are formidable, but the blindness and reductionism of mainstream economics prevents them from being tackled within the discipline which has scarcely been disturbed by the acute exposure of its inadequacies by the crisis.

Alongside then the questioning of neoliberal ideology and policies, the crisis has brought to the fore another crisis that has been going on for many years, that of (orthodox, mainstream or neoclassical) economic theory. It failed to predict and, after the event, fails to offer a convincing explanation of what happened and why. The causes of the current malaise in economics are complex and multifaceted. They include socio-economic, political, ideological, intellectual and institutional factors. Just one of these factors has been the excessive mathematisation and formalisation of economics science. As is well known, following the formalist revolution of the I950s and I960s, or the domination of (mathematical) form over substance, mainstream economics based on methodological individualism and model building has increasingly dominated economic science to an unprecedented degree, at the expense of all other schools, methods and approaches. This total lack of tolerance is another basic attribute of present day economics, alongside a frighteningly intellectually barbaric treatment of history of economic thought and of methodology within the discipline. Concomitant with this formalisation process is a newly acquired self-confidence of the practitioners of this method which was translated into a superiority syndrome vis-à-vis the other social sciences, as exemplified by the process of economics imperialism ` of the Chicago Gary Becker style, or in other words the process of colonisation of other social sciences using the so-called reconomic method to analyse all social phenomena.

Becker's principles or reductionism to individual rationality within a context of "as if" perfectly working markets, has been at most tempered by other behavioural assumptions and appeal to the presence of market imperfections as an explanatory device for both economic and social outcomes. This has itself given rise to the shift to the predominance of macroeconomics to microeconomics (even the denial of the former other than as the latter), further displacing attention to the systemic functioning of the economy. In short, the mainstream has, paradoxically and perversely, extended its scope of analysis whilst narrowing the flawed set of principles on which it does so, claiming that it does so by the standards 
of science. Other causes of mainstream arrogance and intransigence is the institutional monopoly enjoyed by the elite of the profession over the positions in top universities and academic journals, attracting the lion's share of funding, occupying central public positions and being awarded 90 per cent of Nobel prizes in economics. To this should be added the direct vested interests of many academics, especially in the financial sector, a feature that was exacerbated during the past thirty years of financialisation.

\section{The need for alternatives and the contribution of IIPPE}

All of this makes the search for alternatives more necessary than ever. During recent years there are some hopeful signs which may turn the tide towards a more pluralistic and tolerant economic science in touch with real world developments. Most of these developments are taking place outside mainstream economics which hopefully will change the mould of our science. Recently the World Economics Association was launched, together with two new journals (World Economics Journal and Economic Thought) added to the already existing Real World Economics Review, along the lines of the American Economic Association. Within a year it has attracted some I0,000 members compared with the 17,000 members of the American Economic Association, the largest economics association in the world.

The launch of the International Initiative for Promoting Political Economy, IIPPE, which within the first few years of its existence already numbers about 900 members worldwide, is part of this process of the renaissance of political economy and heterodox economics. IIPPE was founded in 2006 and was officially launched in 2008 with the aim of promoting political economy in and of itself but also through critical and constructive engagement with mainstream economics, heterodox alternatives, interdisciplinarity, and activism understood broadly as ranging across formulating progressive policy through to support for progressive movements. Thus, in terms of intellectual content and direction, we see ourselves as commanding and criticising mainstream economics, offering alternatives from within political economy, addressing the nature of contemporary capitalism and corresponding policy and applied issues, and drawing upon and contributing to the presence of political economy, and critique of `economics imperialism where all progressive brands of political economy are welcome. We are keen, however, to avoid continuing sterile and academic controversy at the expense of more constructive engagement across methodological, theoretical, empirical and practical issues. Current intellectual retreats from the extremes, and agenda-setting postures, of postmodernism and neo-liberalism mean that prospects across the social sciences are more open than for a long time, and some lasting and significant influence can be exerted by concertedly promoting political economy both within academia across the social sciences and more widely.

The intention of IIPPE is to promote political economy at a particularly opportune and appropriate moment. As already noted, within the discipline of economics itself, all heterodoxy has been marginalised, and engagement with alternatives is more or less proscribed. Across the other social sciences, though, interest in political economy is stronger than for a long time, especially in the wake of retreat from, and rejection of, the agendas 
set by neo-liberalism and postmodernism. This is evidenced by the strong interest in, and intellectual direction given to, 'globalisation, for example, as a way of characterising the realities of contemporary capitalism. Contribution to debate over contemporary capitalism is a major element in IIPPE's contribution. Especially in the wake of the global financial crisis, it ranges over the nature and causes of the present structure, pace and dynamics of the accumulation of capital at global, national and sectoral levels as well as the implications for developing and transitional economies.

But it also remains important to continue to hold a critical perspective on developments within mainstream economics, and especially, but not exclusively, its more extreme neoliberal forms based on the most horrendously unrealistic assumptions of the representative agent holding rational expectations and the market efficiency hypothesis, and its most recent aggressive attempts to colonise other social sciences. But the ranks of those trained within economics as a discipline and also critical of it are now sorely depleted with little prospect of them being replenished so intolerant is the discipline of alternatives. An important task is to draw upon critical reflection from within economics as much as is possible with dwindling resources. By the same token, there is an increasingly compelling need for political economy to be promoted within other disciplines and across fields and topics that have become perceived as non-economic in light of the strength of interdisciplinary boundaries and an understandable hostility to economics itself as a discipline. For this reason, apart from sustaining a critique of mainstream economics, we wish both to assess and advance political economy as it is now but also to address and engage with its presence across the other social sciences. We believe it needs a stronger and more developed presence, without which the economics content of social science will become subject to capture by orthodoxy and/or arbitrary and fragmented heterodoxy.

What is needed, then, as far as the economics profession is concerned is a move away from the monolithic approach to economic science characteristic of mainstream economics, which fetishises model-building, towards a pluralism of methods and approaches, and away from atomistic approaches towards more systemic, aggregative, dynamic, historicallyspecific and socially-embedded types of analysis of capitalism. In this direction we consider intradisciplinarity and interdisciplinarity as key features of our endeavours. It is essential that economic science becomes once again a social science. Given the asocial, ahistorical and 'positive nature of mainstream economics, political economy is the appropriate vehicle for this journey and especially suited to provide the liaison between economics and other social sciences. We are also keen to address the relationship between political economy and activism, broadly interpreted, especially in view of the drift in academia towards policy advice, consultancy and self-promoting publicity as the core forms taken by its external activity. We consider this as one of the key aspects differentiating IIPPE from other heterodox and political economy associations. 


\section{IIPPE structure and activities}

IIPPE does not have an official structure yet (but we hope to have one in place soon). It is based almost exclusively on the work of volunteers and tries to establish and sustain a network of support for IIPPE, with our main activities being centred around a number of working groups focusing on particular topics. These run themselves subject to conforming to broader IIPPE aims and activities. So far we have working groups around the following themes: financialisation, neoliberalism, Marxist political economy, heterodoxy, social capital, socialism, urban and regional political economy, commodity studies, environment, political economy of work, beyond the developmental state, international political economy, political economy of institutions, international financial institutions, agrarian change, privatisation, political economy of conflict and violence, transition as development and the minerals-energy complex and comparative industrialisation. The activities of our working groups include the organisation of panels and streams in our annual conference, the organisation of mini-conferences and workshops around specific themes, and the publication of working papers series.

Our other activities have included the organisation of three international political economy research workshops in 2007, 2008 and 2009, in Crete, Procida-Naples and Ankara, respectively, and three international political economy conferences in Crete (20I0), Istanbul (2OII) and Paris (2OI2) which incorporated the research workshops as an integral part. The themes of the conferences have been `Beyond the Crisis`, ’Neoliberalism and the Crises of Economic Sciencer and `Economics Crisis and the Outlook for Capitalism`, respectively. Next year's conference will take place in the Hague. These conferences have now become an annual event around which most IIPPE activities are centred. They have taken place in different parts of Europe each year, drawing a large number of participants ( $60-200$ ).

We lay particular emphasis on joining forces and cooperating with other heterodox and political economy associations and journals and in establishing new national political economy associations where they do not exist. As far as national political economy associations are concerned, so far we have established close links with the French, Brazilian, Russian, Greek and Korean Political Economy Associations, and the Turkish Social Sciences Association. Recently the African Association for Promoting Political Economy was launched with aims similar to those of IIPPE. All three of our conferences so far have been organised in association with one or more of these associations. IIPPE has also established close links with Historical Materialism and the Euromemorandum group.

The culmination of these efforts has been the organisation of the joint conference in Paris in July 2012 with the Heterodox Association of Political Economy (AHE) and the French Association of Political Economy (FAPE) which was the biggest political economy and heterodox conference ever and a huge success in all respects, not least with about 860 submissions of papers, 650 participants from about 50 countries including very many from outside Western Europe, I46 parallel sessions, six plenaries, and no less than 13 supporting heterodox and political economy associations and journals. The latter included the European Association for Evolutionary Political Economy (EAEPE), the Association for Institutionalist Thought (AFIT), the Heterodox Economics Newsletter, the World Association for Political 
Economy, the American Journal for Economics and Sociology, the Review of Radical Political Economics, the Review of Political Economy, the Revue de la Regulation, the Revue Française de Socio-économie etc. This joint conference, called by two major international and one of the largest national networks of political economy and social scientists, breathed fresh air into an otherwise moribund intellectual atmosphere and showed the potential dynamism of such cooperations. Taking pluralism as the means, it brought together the community of critical economists from all strands of political economy and heterodox economics in order to discuss the future of the latter and the recent developments in the global economy and in economic science following the global economic crisis. We consider this together with the launch of the World Economics Association as two of the most important developments in political economy and heterodox economics over the recent period.

In addition to all of this we have established a new book series on Political Economy and Development in association with Pluto Press and editors Ben Fine and Dimitris Milonakis, with four titles already published or in press, and we have published two special issues of the journals Forum for Social Economics (guest editor: Dimitris Milonakis) and International Journal of Management Concepts and Philosophy (guest editors: Daniela Tavasci and Marco Boffo) with papers coming mainly but not exclusively from our conferences and workshops. We also publish the IIPPE Newsletter twice a year, while the financialisation working group runs a Financialisation Working Paper Series. This year we launched a new activity by organising a summer school in Marxist political economy in London in June (organisers: Simon Mohun and Elisa Van Waeyenberge). We plan to make this at least an annual event with particular themes on each occasion. We place particular emphasis on pedagogical and educational issues, including the publication of alternative and more pluralistic textbooks and the promotion of alternative and more pluralistic economics curricula. This is an area in which we need to strengthen our presence. For more information about all IIPPE activities and other useful links visit our website: www.iippe.org.

\section{The way forward}

The recent crisis has ideologically and theoretically delegitimised both neoliberalism and mainstream economics but has not brought an end to their ideological and policy dominance. This contradictory development represents an opportune moment for political economy to organise a comeback. The cracks in the establishment are there. They only need to be exploited. IIPPE was established in order to play a role in this reshuffling of the balance of power within the economics profession. Its presence so far has been instrumental in rejuvenating the renewal of interest in political economy. This, however, is a joint task that needs the cooperation and joining of forces of all heterodox and political economy associations and other institutions. This is by no means an easy task but, especially over the last year or so, there are some encouraging signs that this is happening to a growing extent. We need to keep the momentum going if we are to have an impact and redress the balance of power within the economics profession. IIPPE, with its many activities and latest initiatives, seeks to play a major role in this process. 
